\title{
Is the awakening produced by benzodiazepines due to excitatory actions of GABA?
}

\author{
Yehezkel Ben-Ari@
}

\begin{abstract}
Benzodiazepines (BZDs) such as Zolpidem can produce a temporary revival of patients who have been akinetic and apathic for years. The mechanisms underlying this "awakening" reaction are suggested globally to be related to an activation of gamma-aminobutyric acid (GABA) inhibitory systems. However, brain trauma or cerebro-vascular infarcts, like many other pathological insults, are associated with a shift of the polarity of GABA from inhibition to excitation consequently to an increase of intracellular chloride concentration $\left(\left[\mathrm{Cl}^{-}\right]_{\mathrm{i}}\right)$ levels. Experimental and clinical observations suggest that BZDs generate paradoxical reactions in these conditions, hence the transient "awakening". The NKCC1 (Na-K-2Cl co-transporter isoform 1) chloride importer antagonist Bumetanide restores low $\left[\mathrm{Cl}^{-}\right]_{\mathrm{i}}$ levels and an efficient inhibitory drive. It is therefore suggested that the administration of Bumetanide might provide a persistent "awakening" by shifting GABAergic actions from excitation to inhibition and attenuating the mechanism underlying the apathic/akinetic state.
\end{abstract}

\section{Introduction}

Awakening, a temporary revival of patients who have been akinetic, apathic and with no reaction for years following a large brain damage, has been observed after administration of drugs even if the mechanisms underlying them remain unknown. Although rare, the awakenings produced briefly by "sleeping pills" are now well documented [1-3]. Arnst et al. recently reported spectacular effects of Benzodiazepines (BZDs) on a 29 years old patient after a severe hypoxic-ischemic brain injury and following a history of alcohol abuse [4]. The patient suffered from a severe impairment of arousal and difficulty to maintain an arousal state. Magnetic resonance imaging showed signs of diffuse atrophy without hydrocephalus. For 8 years the patient remained mute, akinetic, incontinent, had muscle rigidity and no affective reactions. Following a single dose of Zolpidem $(10 \mathrm{mg})$, the patient "managed to walk while being

\section{Correspondence: ben-ari@neurochlore.fr}

Neurochlore, Fundamental Research Department, Ben-Ari Institute of Neuroarcheology (IBEN), Case 922, Zone Luminy Entreprises Biotech, 163 Avenue de Luminy, 13288, Marseille, Cedex 09, France supported by the staff and phoned his father, who had not heard his son's voice for years. Despite evident retrograde amnesia, going back three years before the brain injury, and an apparent hearing deficit, he was cheerful, alert, and showing interest in the people and objects surrounding him". These transient effects $(2 \mathrm{~h})$ were repeated only for 5 days with a progressive reduction of efficacy, and after that delay BZDs had no effects at all. The treatment could however be efficient for short periods of time subsequently on special occasions, provided that they are infrequent.

Electroencephalogram (EEG) and magnetoencephalogram source-spectral analysis indicate a small but significant increase of beta and gamma band after Zolpidem treatment. It is usually considered that Zolpidem restores globally the excitation/inhibition imbalance due to a reduced GABAergic inhibitory drive [1-5]. Williams and colleagues reported an abrupt reduction of $6-10 \mathrm{~Hz}$ oscillations and the coherence between the two hemispheres in 3 patients with known positive response to Zolpidem [2]. Unfortunately, the alterations produced in Zolpidem non-responders were not investigated. Similar

(c) The Author(s). 2021 Open Access This article is licensed under a Creative Commons Attribution 4.0 International License, which permits use, sharing, adaptation, distribution and reproduction in any medium or format, as long as you give appropriate credit to the original author(s) and the source, provide a link to the Creative Commons licence, and indicate if changes were made. The images or other third party material in this article are included in the article's Creative Commons licence, unless indicated otherwise in a credit line to the material. If material is not included in the article's Creative Commons licence and your intended use is not permitted by statutory regulation or exceeds the permitted use, you will need to obtain permission directly from the copyright holder. To view a copy of this licence, visit http://creativecommons.org/licenses/by/4.0/. 
observations have been made after severe ischemic brain damage and in patients with a variety of brain disorders including severe degenerative ones, notably Parkinson's disease [6-11]. These effects are interpreted as a general restoration of gamma-aminobutyric acid (GABA) inhibition that has been hampered by the insult. However, the exact underlying mechanism and the site of reduced GABAergic inhibitory drive remains conjectural as these cannot readily be determined from EEG measures. If GABAergic inhibition has been impacted, it is fundamental to identify whether and which element of GABAergic mechanisms is deficient to suggest a therapeutic avenue. Considering the wide range of actions of Zolpidem and other BZDs, it is not astonishing that their effects on awakening have not been identified.

Here, I suggest that the paradoxical effects of BZDs are due to a shift of the polarity of GABA actions triggered by the pathological insult: the excitatory actions of GABA in post ischemic networks are increased by BZDs leading to paradoxical reactions. Indeed, the polarity of GABA actions is determined by intracellular chloride concentration $\left(\left[\mathrm{Cl}^{-}\right]_{\mathrm{i}}\right)$ levels. When they are elevated, GABA exerts depolarizing/excitatory actions; and when they are low, GABA exerts hyperpolarizing/inhibitory actions. The shift from hyperpolarizing/inhibitory to depolarizing/excitatory actions has been reported in a wide range of disorders including ischemic insults and degenerative disorders [12-15]. Experimental observations suggest that paradoxical actions of BZDs occur when neurons have high $\left[\mathrm{Cl}^{-}\right]_{\mathrm{i}}$ levels and excitatory actions of GABA [16-18]. Therefore, I suggest that the ephemerous effects of BZDs are due to high $\left[\mathrm{Cl}^{-}\right]_{\mathrm{i}}$ levels and consequent GABAergic excitation. In this scenario, brief awakening by BZDs calls for the combined use of BZDs and agents known to restore inhibition in order to transform the brief effect to a long lasting one.

\section{Activity-dependent dynamic changes of GABAergic inhibition in disease}

The degree of complexity of GABA actions is quite unsurpassed. Many parameters impact the efficacy of GABAergic signals and inhibition: the large number of subunits of GABA receptors that determine the properties of GABAergic currents and pharmacological properties, the localization and distribution of these receptors and their density, the connectivity of different interneurons, the uptake systems that control GABA levels, and the microglia and astrocytes that regulate extracellular ionic distributions. With regards to the connectivity of different types of interneurons, dendrites-targeted interneurons act by controlling the glutamatergic input of principal neurons and the generation of calcium currents, whereas somatic-targeting interneurons innervate hundreds to thousands of principal neurons leading to a synchronized activity in phase with the end of the synaptic current [19-22]. In addition, GABA and Glycine anionic receptor channel complexes have a unique property that is not shared by excitatory glutamatergic signals: the polarity of their actions depends largely on the levels of ongoing activity. Hyperactivity and a wide range of insults produce an accumulation of chloride ions leading to depolarizing and often excitatory effects of GABA [23-25]. Excitatory GABAergic signals can activate sodium channels, voltage-gated currents and remove the voltage-dependent blockade of NMDA receptor channels, leading to calcium influx with important long-lasting consequences on plasticity and network operation [23, 26-28].

The polarity of GABA actions also follows a developmental trajectory shifting from depolarizing/excitatory to hyperpolarizing/inhibitory in all animal species investigated [23, 29-32]. This is due to an evolutionary conserved progressive reduction of $\left[\mathrm{Cl}^{-}\right]_{\mathrm{i}}$ levels mediated by a decrease in the activity of a major chloride importer $\mathrm{NKCC} 1$ (Na-K-2Cl co-transporter isoform 1) and an increase of the chloride exporter $\mathrm{KCC} 2$ (K-Cl cotransporter isoform 2) activity [23, 25] (Fig. 1). During development GABAergic signals modulate cell proliferation, neuronal migration and growth as well as synapse and neuronal ensemble formation [23, 33-35]. The developmental stage at which the shift occurs is animal species, brain structure and sex specific [23]. In addition, there is an oxytocin-mediated neuroprotective transient shift to hyperpolarizing actions during parturition and birth [36, 37]. In experimental conditions, blocking the depolarizing actions of GABA by knocking out KCC2 or by in utero administration of NKCC1 antagonists produces deleterious effects including epilepsy and abnormal behavior in mice [17, 38-41].

Quite astonishingly, extensive investigations have unraveled a return to high $\left[\mathrm{Cl}^{-}\right]_{\mathrm{i}}$ levels and excitatory actions of GABA in many disorders and pathological conditions. This has been observed in rodent models of disorders that are generated in utero including Autism Spectrum Disorders (ASD), Fragile X, Rett and Down syndromes, maternal immune activation, various infantile epilepsies due to migration disorders, etc [12, 18, 4153] Similar alterations are observed also in neurodegenerative disorders and adult insults or lesions including spinal cord injury, chronic pain, brain trauma, Parkinson's disease, Huntington's disease, deleterious actions of anesthetic agents, etc $[12,14,54-62] \mathrm{High}\left[\mathrm{Cl}^{-}\right]_{\mathrm{i}}$ levels and a disruption of ionic equilibrium are also observed in brain tumors, notably neuro-glioblastoma [6367]. The higher $\left[\mathrm{Cl}^{-}\right]_{\mathrm{i}}$ levels are due to a higher NKCC1/ KCC2 activity ratio. Brain infarct also leads to similar changes with high $\left[\mathrm{Cl}^{-}\right]_{\mathrm{i}}$ levels and depolarizing/excitatory actions of GABA. Moderate to severe ischemic 


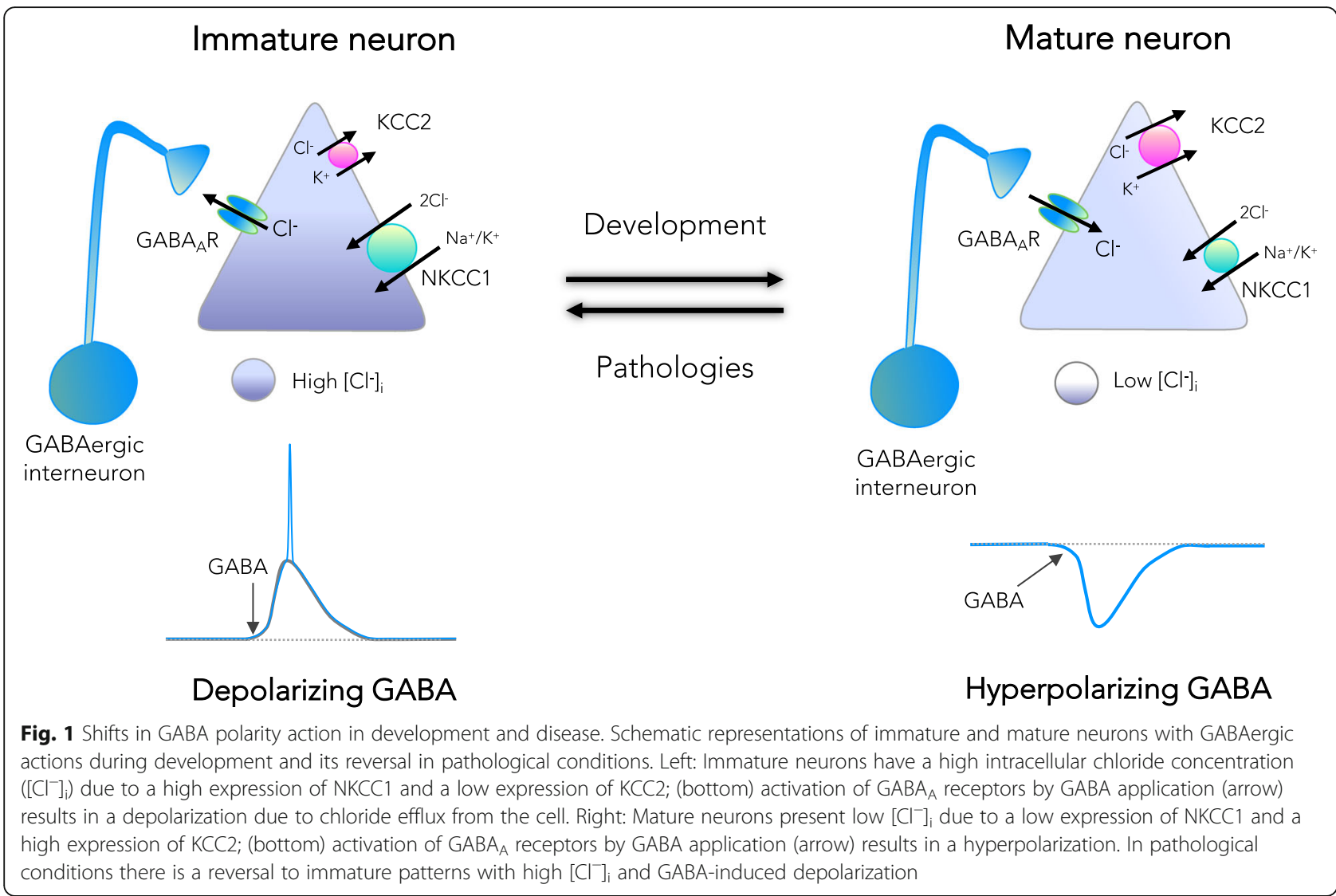

conditions increase $\mathrm{NKCC} 1$ and/or reduce $\mathrm{KCC} 2$ activity [40, 68-75]. Therefore, in spite of the heterogeneity of these insults and their generating pathogenic event, they share a common reaction associated with high $\left[\mathrm{Cl}^{-}\right]_{\mathrm{i}}$ levels and depolarizing/excitatory actions of GABA (Fig. $1)$. Events underlying this shift include activation of kinases regulating $\mathrm{NKCC} 1$ and $\mathrm{KCC} 2$, and brain-derived neurotrophic factor released by microglia [40, 76-78]. Collectively, these observations illustrate the dynamic changes of GABA actions, the central role of the $\mathrm{NKCC} 1 / \mathrm{KCC} 2$ ratio and their importance in the pathogenesis of infarcts and severe brain damage.

Restoring low $\left[\mathrm{Cl}^{-}\right]_{\mathrm{i}}$ levels and GABAergic inhibition has been shown to attenuate many brain disorders in experimental conditons and in clinical trials. The most frequently used agent to reduce $\left[\mathrm{Cl}^{-}\right]_{\mathrm{i}}$ levels is Bumetanide, a highly specific antagonist of the ubiquitously expressed NKCC1 chloride importer and the NKCC2 chloride cotransporter present in the thick ascending loop of Henle, hence its diuretic action. In animal models, Bumetanide attenuates the severity of ASD, Parkinson's disease, chronic pain, epilepsies, anesthesia induced seizures, etc [12, 71, 79-84] Furthermore, Bumetanide reduces ischemic infarction, cerebral swelling and neurological sequels in mice [71]. Successful clinical trials have also been made using Bumetanide with the aim of reducing
$\left[\mathrm{Cl}^{-}\right]_{\mathrm{i}}$ levels to treat ASD [85-88] and related genetic syndromes with autistic features such as Tuberous Sclerosis [89]. Pilot trials also show a similar efficacy to treat Fragile X syndrome [90], schizophrenia [9] and Parkinson's disease [91]. Collectively, these studies suggest that the reduction of high $\left[\mathrm{Cl}^{-}\right]_{\mathrm{i}}$ levels and the shift of the polarity of GABA from excitation to inhibition might pave the way to innovative therapies of many disorders.

\section{A working hypothesis: complementarity of Zolpidem and Bumetanide}

Paradoxical actions of BZD are also observed after anesthesia where increasing doses of BZDs shift the effects from sedation to a paradoxical reaction with euphoria or dysphoria and purposeless movements [92]. How does Zolpidem and related agents produce these paradoxical reactions? Here, I propose that aberrant high $\left[\mathrm{Cl}^{-}\right]_{\mathrm{i}}$ levels and excitatory actions of GABA underlie the "awakening" produced by BZDs. In a comatose state, BZDs enhance the excitatory GABAergic activity leading to a paradoxical transient awakening instead of sleep and reduced activity. As such, this suggests that GABA exerts excitatory actions. Bumetanide might then restore low $\left[\mathrm{Cl}^{-}\right]_{\mathrm{i}}$ levels and efficient GABAergic inhibitory drive, decreasing the fundamental consequence of the initial trauma. Paradoxical effects of BZDs have been 
demonstrated in experimental conditions when $\left[\mathrm{Cl}^{-}\right]_{\mathrm{i}}$ levels are high and the actions of GABA excitatory [41, 93, 94]. Phenobarbital also exerts paradoxical effects reducing early seizures but aggravating repeated ones when $\left[\mathrm{Cl}^{-}\right]_{\mathrm{i}}$ levels are increased [41]. In keeping with this, a pilot study reported that Bumetanide attenuated the severity of ASD and BZDs produced paradoxical reactions [95]. Collectively these observations raise the possibility that the paradoxical effects of BZDs are mediated by GABA excitatory actions that BZDs reinforce. Since $\left[\mathrm{Cl}^{-}\right]_{\mathrm{i}}$ levels cannot be determined in humans, these paradoxical actions of BZDs might justify the use of Bumetanide to reduce the potantially high $\left[\mathrm{Cl}^{-}\right]_{\mathrm{i}}$ levels, restore inhibition and attenuate the core apathic and akinetic syndrome.

Therefore, two agents acting differently on GABAergic networks, Zolpidem and Bumetanide, might emerge as potentially useful producing an awakening reaction. The former produces transient awakening effects that are not readily reproduced with repeated administration, the latter by reducing $\left[\mathrm{Cl}^{-}\right]_{\mathrm{i}}$ levels restores persistently GABA polarity and the efficacy of inhibitory networks. The use of Bumetanide is safe with minimal side effects even when administered for long periods, and it has been used for decades to treat hypertension and brain oedema with easily controlled side effects [96]. The administration of Bumetanide alone or possibly in combination with BZDs might therefore produce long term persistent awakening. This has been tested efficiently in a co-administration of BZD and Acetazolamide - a carbonic anhydrase inhibitor that reduces $\left[\mathrm{Cl}^{-}\right]_{i}$ - showing an enhanced effect compared to the administration of BZD alone [60]. Also, Bumetanide enhances BZD efficacy in ischemic damage [13], and seizures are efficiently reduced by combined administration of Phenobarbital or BZDs and Bumetanide [94, 97]. Therefore, a dual drug administration has shown some efficacy in these pathologies.

\section{Conclusion}

In conclusion, paradoxical actions of BZDs can be viewed as a clinical signal reflecting a disturbance of the regulation of $\left[\mathrm{Cl}^{-}\right]_{\mathrm{i}}$ levels and the polarity of GABA. It is therefore suggested that a similar mechanism might operate in these patients. This also suggests that Bumetanide, known in experimental and clinical situations (pilot cases) to reduce/attenuate the severity of an insult, might be useful to correct the fundamental cause of the disorder. Clearly, low $\left[\mathrm{Cl}^{-}\right]_{\mathrm{i}}$ levels constitute a general signature of insults that must be treated by restoring the correct polarity of GABA actions.

\section{Abbreviations}

ASD: Autism Spectrum Disorders; BZDs: Benzodiazepines;

EEG: Electroencephalogram; GABA: Gamma-aminobutyric acid; KCC2: K-Cl cotransporter isoform 2; NKCC1: Na-K-Cl co-transporter isoform 1

\section{Acknowledgements}

I thank Dr. D Ferrari for her comments and suggestions and Dr. C Dumon for her help with the Figure.

\section{Author's contributions \\ Y B-A wrote the manuscript. The author(s) read and approved the final manuscript.}

\section{Funding}

Yehezkel Ben-Ari's work is supported by Neurochlore.

\section{Availability of data and materials}

Not applicable.

Ethics approval and consent to participate

Not applicable.

\section{Consent for publication}

Not applicable.

\section{Competing interests}

Yehezkel Ben-Ari is the CEO and a shareholder of Neurochlore, a biotech company dedicated to the development of treatments for children with autism.

Received: 18 December 2020 Accepted: 9 February 2021

Published online: 16 February 2021

\section{References}

1. Sutton JA, Clauss RP. A review of the evidence of zolpidem efficacy in neurological disability after brain damage due to stroke, trauma and hypoxia: a justification of further clinical trials. Brain Inj. 2017;31:1019-27.

2. Williams ST, et al. Common resting brain dynamics indicate a possible mechanism underlying zolpidem response in severe brain injury. Elife. 2013; 2:1-22.

3. Machado C, Estévez M, Rodriguez-Rojas R. Zolpidem efficacy and safety in disorders of consciousness. Brain Inj. 2018;32:530-1.

4. Arnts $\mathrm{H}$, et al. Awakening after a sleeping pill: restoring functional brain networks after severe brain injury. Cortex. 2020;132:135-46.

5. Clauss RP, Güldenpfennig WM, Nel HW, Sathekge MM, Venkannagari RR. Extraordinary arousal from semi-comatose state on zolpidem. South African Med J. 2000;90:68-72

6. Bomalaski MN, Claflin ES, Townsend W, Peterson MD. Zolpidem for the treatment of neurologic disorders: a systematic review. JAMA Neurol. 2017; 74:1130-9.

7. Prokic EJ, et al. Cortical oscillatory dynamics and benzodiazepine-site modulation of tonic inhibition in fast spiking interneurons. Neuropharmacology. 2015;95:192-205.

8. Daniele A, Panza F, Greco A, Logroscino G, Seripa D. Can a Positive Allosteric Modulation of GABAergic Receptors Improve Motor Symptoms in Patients with Parkinson's Disease? The Potential Role of Zolpidem in the Treatment of Parkinson's Disease. Parkinsons Dis. 2016;14:1-15.

9. Lemonnier $E$, Lazartigues A, Ben-Ari Y. Treating schizophrenia with the diuretic bumetanide: a case report. Clin Neuropharmacol. 2016;39:115-7.

10. Hall SD, et al. GABA(a) alpha-1 subunit mediated desynchronization of elevated low frequency oscillations alleviates specific dysfunction in stroke a case report. Clin Neurophysiol. 2010;121:549-55.

11. Hall SD, et al. GABA-mediated changes in inter-hemispheric beta frequency activity in early-stage Parkinson's disease. Neuroscience. 2014;281:68-76.

12. Ben-Ari Y. NKCC1 chloride importer antagonists attenuate many neurological and psychiatric disorders. Trends Neurosci. 2017:40:536-54.

13. Cleary RT, et al. Bumetanide enhances phenobarbital efficacy in a rat model of hypoxic neonatal seizures. PLoS One. 2013:8:1-12.

14. Hasbargen T, et al. Role of NKCC1 and KCC2 in the development of chronic neuropathic pain following spinal cord injury. Ann N Y Acad Sci. 2010;1198: 168-72.

15. Kahle KT, Staley KJ. The bumetanide-sensitive Na-K-2Cl cotransporter NKCC1 as a potential target of a novel mechanism-based treatment strategy for neonatal seizures. Neurosurg Focus. 2008;25:1-8. 
16. Nardou R, et al. Phenobarbital but not diazepam reduces AMPA/kainate receptor mediated currents and exerts opposite actions on initial seizures in the neonatal rat Hippocampus. Front Cell Neurosci. 2011;5:16.

17. Khalilov I, et al. Enhanced synaptic activity and epileptiform events in the embryonic KCC2 deficient hippocampus. Front Cell Neurosci. 2011;5:1-8.

18. Ben-Ari Y, Khalilov I, Kahle KT, Cherubini E. The GABA excitatory/inhibitory shift in brain maturation and neurological disorders. Neuroscientist. 2012;18: 467-86.

19. Freund TF, Buzsáki G. Interneurons of the hippocampus. Hippocampus. 1996;6:347-470.

20. Klausberger T, Somogyi P. Neuronal diversity and temporal dynamics: the unity of hippocampal circuit operations. Science. 2008;321:53-7.

21. Klausberger $\mathrm{T}$, et al. Brain-state- and cell-type-specific firing of hippocampal interneurons in vivo. Nature. 2003;421:844-8.

22. Somogyi $\mathrm{P}$, Katona L, Klausberger T, Lasztóczi B, Viney TJ. Temporal redistribution of inhibition over neuronal subcellular domains underlies state-dependent rhythmic change of excitability in the hippocampus. Philosophical Transact R Soc B Biol Sci. 2014;369(1635):33-48.

23. Ben-Ari Y, Gaiarsa JL, Tyzio R, Khazipov R. GABA: a pioneer transmitter that excites immature neurons and generates primitive oscillations. Physiol Rev. 2007;87:1215-84

24. Kaila $\mathrm{K}$, et al. The $\mathrm{K}+/ \mathrm{Cl} \mid[$ minus] | co-transporter KCC2 renders GABA hyperpolarizing during neuronal maturation. Nature. 1999;397:251-5.

25. Rivera $\mathrm{C}$, et al. The $\mathrm{K}+\mathrm{Cl}$ - co-transporter $\mathrm{KCC} 2$ renders GABA hyperpolarizing during neuronal maturation. Nature. 1999;397:251-5.

26. Ben-Ari $Y$, et al. Neurophysiology. 2002;34:81-2.

27. Leinekugel $X$, Tseeb V, Ben-Ari Y, Bregestovski P. Synaptic GABAA activation induces $\mathrm{Ca} 2+$ rise in pyramidal cells and interneurons from rat neonatal hippocampal slices. J Physiol. 1995;487:319-29.

28. Fiumelli H, Woodin MA. Role of activity-dependent regulation of neuronal chloride homeostasis in development. Curr Opin Neurobiol. 2007;17:81-6.

29. Khazipov R, et al. Early development of neuronal activity in the primate hippocampus in utero. J Neurosci. 2001;21:9770-81.

30. Achilles $\mathrm{K}$, et al. Kinetic properties of $\mathrm{cl}$ - uptake mediated by $\mathrm{Na}$ +-dependent $\mathrm{K}+-2 \mathrm{Cl}$ - cotransport in immature rat neocortical neurons. J Neurosci. 2007;27:8616-27.

31. Yamada J, et al. Cl- uptake promoting depolarizing GABA actions in immature rat neocortical neurones is mediated by NKCC1. J Physiol. 2004 557:829-41.

32. Tyzio $R$, et al. Postnatal changes in somatic $\gamma$-aminobutyric acid signalling in the rat hippocampus. Eur J Neurosci. 2008;27:2515-28.

33. Dammerman RS, Flint AC, Noctor $S$, Kriegstein AR. An excitatory GABAergic plexus in developing neocortical layer 1. J Neurophysiol. 2000;84:428-34.

34. Chen J, Kriegstein AR. A GABAergic projection from the zona incerta to cortex promotes cortical neuron development. Science. 2015;350(80):554-8.

35. Kriegstein AR. GABA puts the brake on stem cells. Nat Neurosci. 2005;8: 1132-3.

36. Tyzio $R$, et al. Maternal oxytocin triggers a transient inhibitory switch in GABA signaling in the fetal brain during delivery. Science. 2006;314(80):1788-92.

37. Leonzino $M$, et al. The timing of the excitatory-to-inhibitory GABA switch is regulated by the oxytocin receptor via KCC2. Cell Rep. 2016;15:96-103.

38. Wang DD, Kriegstein AR. Blocking early GABA depolarization with bumetanide results in permanent alterations in cortical circuits and sensorimotor gating deficits. Cereb Cortex. 2011;21:574-87.

39. Chudotvorova I, et al. Early expression of KCC2 in rat hippocampal cultures augments expression of functional GABA synapses. J Physiol. 2005;566:671-9.

40. Pellegrino $C$, et al. Knocking down of the KCC2 in rat hippocampal neurons increases intracellular chloride concentration and compromises neuronal survival. J Physiol. 2011;589:2475-96.

41. Nardou R, et al. Neuronal chloride accumulation and excitatory GABA underlie aggravation of neonatal epileptiform activities by phenobarbital. Brain. 2011;134:987-1002.

42. Tyzio R, et al. Oxytocin-mediated GABA inhibition during delivery attenuates autism pathogenesis in rodent offspring. Science. 2014;343(80):675-9.

43. Watanabe M, Fukuda A. Development and regulation of chloride homeostasis in the central nervous system. Front Cell Neurosci. 2015;9:1-14.

44. Lapray D, et al. Spontaneous epileptic manifestations in a DCX knockdown model of human double cortex. Cereb Cortex. 2010;20:2694-701.

45. Rheims S, Represa A, Ben-Ari Y, Zilberter Y. Layer-specific generation and propagation of seizures in slices of developing neocortex: role of excitatory GABAergic synapses. J Neurophysiol. 2008;100:620-8.
46. Knuesel I, et al. Maternal immune activation and abnormal brain development across CNS disorders. Nat Rev Neurol. 2014;10:643-60.

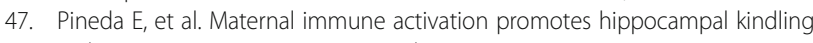
epileptogenesis in mice. Ann Neurol. 2013;74:11-9.

48. Fernandez $A$, et al. The GABA developmental shift is abolished by maternal immune activation already at birth. Cereb Cortex. 2019;29:3982-92.

49. Robertson CE, Ratai EM, Kanwisher N. Reduced GABAergic action in the autistic brain. Curr Biol. 2016;26:80-5.

50. Nabekura J, et al. Reduction of KCC2 expression and GABAA receptormediated excitation after in vivo axonal injury. J Neurosci. 2002;22:4412-7.

51. Khalilov I, Le Van Quyen M, Gozlan H, Ben-Ari Y. Epileptogenic actions of GABA and fast oscillations in the developing Hippocampus. Neuron. 2005; 48:787-96.

52. Lozovaya N, et al. Early alterations in a mouse model of Rett syndrome: the GABA developmental shift is abolished at birth. Sci Rep. 2019;9:9276.

53. Hyde TM, et al. Expression of GABA signaling molecules KCC2, NKCC1, and GAD1 in cortical development and schizophrenia. J Neurosci. 2011:31: 11088-95.

54. Lozovaya N, et al. GABAergic inhibition in dual-transmission cholinergic and GABAergic striatal interneurons is abolished in Parkinson disease. Nat Commun. 2018;9:1422

55. Gagnon M, et al. Chloride extrusion enhancers as novel therapeutics for neurological diseases. Nat Med. 2013;19:1524-8.

56. Epsztein J, et al. Ongoing epileptiform activity in the post-ischemic hippocampus is associated with a permanent shift of the excitatoryinhibitory synaptic balance in CA3 pyramidal neurons. J Neurosci. 2006;26: 7082-92.

57. van den Pol AN, Obrietan K, Chen G. Excitatory actions of GABA after neuronal trauma. J Neurosci. 1996;16:4283-92.

58. Dargaei $Z$, et al. Restoring GABAergic inhibition rescues memory deficits in a Huntington's disease mouse model. Proc Natl Acad Sci U S A. 2018;115: E1618-26.

59. Holmes GL, Ben-Ari Y. Seizing hold of seizures. Nat Med. 2003;9:994-6.

60. Asiedu M, Ossipov MH, Kaila K, Price TJ. Acetazolamide and midazolam act synergistically to inhibit neuropathic pain. Pain. 2010;148:302-8.

61. Tian Y, Lei T, Yang Z, Zhang T. Urethane suppresses hippocampal CA1 neuron excitability via changes in presynaptic glutamate release and in potassium channel activity. Brain Res Bull. 2012;87:420-6.

62. Ma H, et al. NKCC1 promotes EMT-like process in GBM via RhoA and Rac1 signaling pathways. J Cell Physiol. 2019:234:1630-42.

63. Garzon-Muvdi T, et al. Regulation of brain tumor dispersal by NKCC1 through a novel role in focal adhesion regulation. PLoS Biol. 2012;10(5): e1001320.

64. Ye ZY, Li DP, Byun HS, Li L, Pan HL. NKCC1 upregulation disrupts chloride homeostasis in the hypothalamus and increases neuronal activitysympathetic drive in hypertension. J Neurosci. 2012;32:8560-8.

65. Cuddapah VA, Sontheimer $\mathrm{H}$. Ion channels and tranporters in cancer. 2. Ion channels and the control of cancer cell migration. Am J Physiol Cell Physiol. 2011;301:1-16.

66. Algharabil J, et al. Inhibition of $\mathrm{Na}-\mathrm{K}+-2 \mathrm{Cl}$ - cotransporter isoform 1 accelerates temozolomidemediated apoptosis in glioblastoma cancer cells. Cell Physiol Biochem. 2012;30:33-48.

67. Turner $\mathrm{KL}$, Sontheimer $\mathrm{H}$. Cl- and $\mathrm{K}+$ channels and their role in primary brain tumour biology. Philosophical Transact R Soc B Biol Sci. 2014; 369(1638):20130095.

68. Foroutan S, Brillault J, Forbush B, O'Donnell ME. Moderate-to-severe ischemic conditions increase activity and phosphorylation of the cerebral microvascular endothelial cell $\mathrm{Na}+-\mathrm{K}+-\mathrm{Cl}$ - cotransporter. Am J Physiol - Cell Physiol. 2005;289(6):C1492-501.

69. Ducsay CA, et al. Gestational hypoxia and developmental plasticity. Physiol Rev. 2018;98:1241-334.

70. Zhang J, et al. Inhibition of $\mathrm{Na}+-\mathrm{K}+-2 \mathrm{Cl}$ - cotransporter attenuates bloodbrain-barrier disruption in a mouse model of traumatic brain injury. Neurochem Int. 2017:111:23-31.

71. Huang $\mathrm{H}$, et al. A novel Na+-K+-Cl- Cotransporter 1 inhibitor STS66* reduces brain damage in mice after ischemic stroke. Stroke. 2019;50:1021-5.

72. Yan Y, Dempsey RJ, Sun D. Na+-K+-cl- cotransporter in rat focal cerebral ischemia. J Cereb Blood Flow Metab. 2001:21:711-21.

73. Chen H, Luo J, Kintner DB, Shull GE, Sun D. Na+-dependent chloride transporter (NKCC1)-null mice exhibit less gray and white matter damage after focal cerebral ischemia. J Cereb Blood Flow Metab. 2005;25:54-66. 
74. Jaenisch N, Witte OW, Frahm C. Downregulation of potassium chloride cotransporter KCC2 after transient focal cerebral ischemia. Stroke. 2010;41(3): s151-s159.

75. Pond BB, Galeffi F, Ahrens R, Schwartz-Bloom RD. Chloride transport inhibitors influence recovery from oxygen-glucose deprivation-induced cellular injury in adult hippocampus. Neuropharmacology. 2004;47:253-62.

76. Lavertu G, Côté SL, De Koninck Y. Enhancing K-cl co-transport restores normal spinothalamic sensory coding in a neuropathic pain model. Brain. 2014;137:724-38.

77. Doyon N, Vinay L, Prescott SA, De Koninck Y. Chloride regulation: a dynamic equilibrium crucial for synaptic inhibition. Neuron. 2016;89:1157-72.

78. Chen SR, et al. Increased spinal cord Na+-K+-2Cl- cotransporter-1 (NKCC1) activity contributes to impairment of synaptic inhibition in paclitaxelinduced neuropathic pain. J Biol Chem. 2014;289:31111-20.

79. Edwards DA, et al. Bumetanide alleviates epileptogenic and neurotoxic effects of sevoflurane in neonatal rat brain. Anesthesiology. 2010;112: 567-75.

80. James BJ, Gales MA, Gales BJ. Bumetanide for autism Spectrum disorder in children: a review of randomized controlled trials. Ann Pharmacother. 2018; 4:1060028018817304.

81. Cellot G, Cherubini E. GABAergic signaling as therapeutic target for autism spectrum disorders. Front Pediatr. 2014:2:70

82. Conti $\mathrm{L}$, et al. Anomalous levels of $\mathrm{cl}$ - transporters cause a decrease of GABAergic inhibition in human peritumoral epileptic cortex. Epilepsia. 2011; 52:1635-44.

83. Haas BR, Sontheimer H. Inhibition of the sodium-potassium-chloride cotransporter isoform-1 reduces glioma invasion. Cancer Res. 2010;70: 5597-606.

84. Shulga A, et al. The loop diuretic bumetanide blocks posttraumatic p75 NTR upregulation and rescues injured neurons. J Neurosci. 2012;32:1757-70.

85. Hadjikhani N, et al. Improving emotional face perception in autism with diuretic bumetanide: a proof-of-concept behavioral and functional brain imaging pilot study. Autism. 2015;19:149-57.

86. Ravel $\mathrm{D}$, et al. Effects of bumetanide on neurobehavioral function in children and adolescents with autism spectrum disorders. Transl Psychiatry. 2017;7:e1056.

87. Zhang $\mathrm{L}$, et al. Symptom improvement in children with autism spectrum disorder following bumetanide administration is associated with decreased GABA/glutamate ratios. Transl Psychiatry. 2020;10:9.

88. Du L, et al. A pilot study on the combination of applied behavior analysis and Bumetanide treatment for children with autism. J Child Adolesc Psychopharmacol. 2015;25:585-8

89. Van Andel DM, et al. Effects of bumetanide on neurodevelopmental impairments in patients with tuberous sclerosis complex: an open-label pilot study. Mol Autism. 2020;11(1):1-14.

90. Lemonnier $E$, et al. Treating fragile $X$ syndrome with the diuretic bumetanide: a case report. Acta Paediatr Int J Paediatr. 2013;102:2007-9.

91. Damier P, Hammond C, Ben-Ari Y. Bumetanide to treat Parkinson disease: a report of 4 cases. Clin Neuropharmacol. 2016;39:57-9.

92. Brown EN, Lydic R, Schiff ND. General anesthesia, sleep, and coma. N Engl J Med. 2010;363:2638-50.

93. Glykys J, Staley KJ. Diazepam effect during early neonatal development correlates with neuronal CI(.). Ann Clin Transl Neurol. 2015;2:1055-70.

94. Dzhala VI, et al. NKCC1 transporter facilitates seizures in the developing brain. Nat Med. 2005;11:1205-13.

95. Bruining $\mathrm{H}$, et al. Paradoxical Benzodiazepine Response: A Rationale for Bumetanide in Neurodevelopmental Disorders? Pediatrics. 2015;136: e539-43.

96. Kharod SC, Kang SK, Kadam SD. Off-label use of bumetanide for brain disorders: An overview. Front Neurosci. 2019;24(13):310.

97. Dzhala VI, Brumback AC, Staley KJ. Bumetanide enhances phenobarbital efficacy in a neonatal seizure model. Ann Neurol. 2008;63:222-35.

\section{Publisher's Note}

Springer Nature remains neutral with regard to jurisdictional claims in published maps and institutional affiliations.

Ready to submit your research? Choose BMC and benefit from:

- fast, convenient online submission

- thorough peer review by experienced researchers in your field

- rapid publication on acceptance

- support for research data, including large and complex data types

- gold Open Access which fosters wider collaboration and increased citations

- maximum visibility for your research: over $100 \mathrm{M}$ website views per year

At BMC, research is always in progress.

Learn more biomedcentral.com/submissions 